\title{
Fiscal legitimacy of environmental taxation: challenges for green growth policy
}

\author{
Edi Slamet Irianto ${ }^{1}$, Haula Rosdiana, ${ }^{2, *}$, Lucas Filberto Sardjono ${ }^{2}$, and Maria R. U. D. \\ Tambunan $^{2}$ \\ ${ }^{1}$ Graduate Program of tax Policy and Administrative Science, Faculty of Administrative Science, \\ Universitas Indonesia, Depok, Indonesia \\ ${ }^{2}$ Faculty of Administrative Science, Universitas Indonesia, Depok, Indonesia
}

\begin{abstract}
In Indonesia the fiscal legitimacy of environmental taxation has not received serious attention from tax experts. This is proved by the limited number of studies investigating it. There are at least three interesting perspectives. First, the Indonesian perspective as a country, this research is very necessary and the results are awaited in order to get answers to the failure of Indonesia in application of environmental taxes. Second, policy maker perspective, the result of this research is needed to build policy based on evidence and Third, scientific perspective to introduce contemporary tax paradigm that should be well understood by government and society. It is in this context that the tax essence adequately can be well known in the structure, the posture of state levies and its impact on the productivity and competitiveness of society. This research aims to explain the implications if the government implements new environmental taxes (e.g. environmental taxes) and challenges of fiscal legitimacy from environmental taxes within the framework of green growth policy. By using constructivism paradigm, this research is done through documentation and literature study, and technical data analysis in the form of meta-analysis. The research results show that there are some pseudo environmental taxes and charges applied in Indonesia. That is, if the government impose a new tax type, then the government will add compliance costs and distort entrepreneur cash flow. However, if the government can manage revenue from environmental taxes and charges through good spending quality, it will create tax justification that will rise the tax trust. Therefore, spending quality should be done transparently, accountably and consistently, to ensure that environmental taxes that do not cause high economic costs, do not reduce competitiveness, and ensure the stability of state revenues. Thus, the restructuring, convergence and harmonization of environmental taxes and charges must be conducted in order to achieve a connection between tax payments and inclusive and sustainable economic growth can be created.
\end{abstract}

\footnotetext{
* Corresponding author: h.rosdiana@ui.ac.id
} 


\section{Introduction}

Taxes are often regarded as effective social, economic and political engineering, so that governments often use it as the instruments in achieving government programs. Although its effectiveness is still often questionable, yet belief that taxes can overcome the problem of negative externalities led to theories like pigouvian tax [1] still considered relevant today. Environmental taxes had been increasingly used to influence the behaviour of economic actors whether producers or consumers [16], can encourage more environmentally responsible behaviour [17] and make the economic actors using resources and energy more efficiently [19]. However, taxation would be a boomerang for the government if the government is too excessive without being able to build a fiscal legitimacy for the various taxes that imposed [2]. In this context, it will be explained why environmental taxes are opposed and fail to apply in Indonesia.

Currently, there are five theories that discuss environmental tax, namely (1) polluterpays principle; (2) precautionary principle; (3) least-cost abatement; (4) double dividend theory; and (5) microeconomic approaches [1]. Environmental tax is rooted in the tax function as a regulatory instrument to overcome market failures due to negative externalities [18], i.e. "situations where economic activity results in social costs which are not paid for the producer or the consumer who causes them."[3]. In practice, often, producers do not fully bear the costs incurred due to hazardous factory waste, which is an excess of a goods production process. In some cases, factory waste has an impact on the destruction of the environment [4] and then the communities who bear such costs or side effects. If that happens, then the government must also be responsible to overcome it. Smoke from factory as an excess of iron production process, can pollute the air. If there is no government intervention, massive iron production will aggravate air pollution and may cause respiratory illness. The market does not deal with such a complex problem and the market has no authority to limit its adverse effects and to punish every person or institution that causes it. Therefore, the state that must function as a Regulator, among others by requiring entrepreneurs to make an analysis of environmental impacts as a form of environmental behavior [5], create a waste disposal site and/or by tax collection.

In dealing with negative externalities, economists generally advocate tax collection instruments because they are considered more efficient to reduce pollution than if the government only makes regulations about pollution. Tax collection will affect the price thus affecting the shifting supply curve (see Figure 1).

However, tax theory to overcome negative externalities should not stand alone and isolated with other tax theories, so that the policy formulation is not partial, not comprehensive and not holistic so that the purpose of tax collection is not achieved. It is in this context that a fiscal legitimacy perspective is needed so that taxation can strengthen the relations between state and people in achieving the goals of the nation and the state. 


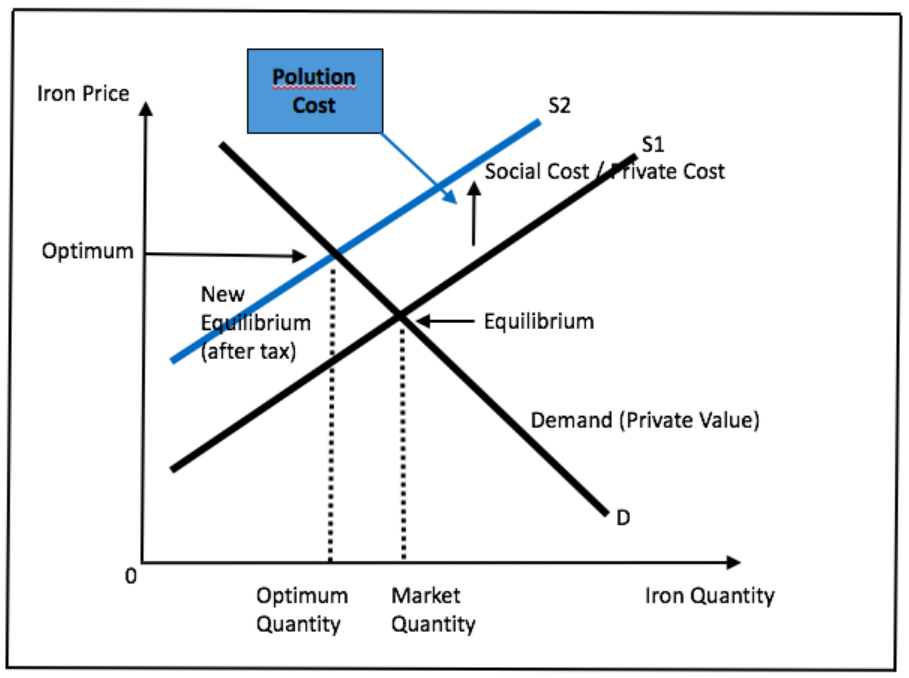

Fig. 1. Iron market after government intervention (through tax collection).

Source: Mankiw, idea modified by Rosdiana and Irianto, 2015

\section{Research Methodology}

This research is conducted by using constructivism paradigm. Through this paradigm the researcher understands, interprets, and analyzes social phenomena from the collected data. The meaning of social reality is built and then constructed with a cognitive scheme through a structured concept. The research method occupies qualitative approach by using inductive principle. Data collection is done through documentation and literature studies. The data collected comes from various regulation that related to pseudo environmental taxes \& charges in Indonesia. Data analysis technique is meta-analyzes, with retrospective observational studies to provide a holistic overview of a phenomenon under review. Metaanalysis was raised to address research issues in various social sciences. Meta-analysis can make visible findings contradictory and difficult to accumulate, becoming more integrative and systematic [6].

\section{Result and Discussion}

Although environmental taxes have failed to apply in Indonesia, but essentially, there are several types of taxes that are pseudo environmental taxes, such as Street Lighting Tax (PPJ), Motor Vehicle Fuel Tax (PBBKB), Motor Vehicle Tax (PKB), Surface Water Tax (PAP), and Underground Water Tax (PABT). The tax rate, the tax base, and the tax revenue utilization allocation are shown in Table 1.

Table 1 describes the various taxes that can be categorized as environmental taxes that have been applied in Indonesia. In general, it can be seen that earmarking has not been applied clearly and firmly. Therefore, it is understandable why people have not yet felt strong fiscal legitimacy over these tax levies. 
Table 1. Environmental taxes in Indonesia.

\begin{tabular}{|c|c|c|c|}
\hline Variety of Taxes & Tax Rate & Tax Base & $\begin{array}{r}\text { Spending } \\
\text { Allocation }\end{array}$ \\
\hline $\begin{array}{l}\text { Motor Vehicle Tax } \\
\text { (PKB) }\end{array}$ & $\begin{array}{l}\text { 1. The first ownership } \\
\text { is at least } 1 \% \text { and } \\
\text { the is highest } 2 \% \text {; } \\
\text { 2. The second and } \\
\text { subsequent } \\
\text { ownership is set } \\
\text { progressively at the } \\
\text { minimum } 2 \% \text { and at } \\
\text { the maximum } 10 \% \text {. }\end{array}$ & $\begin{array}{l}\text { 1. Selling Value of Motor } \\
\text { Vehicle; and } \\
\text { 2. Weight that reflects the } \\
\text { relative degree of road } \\
\text { damage and / or } \\
\text { environmental pollution } \\
\text { caused by the use of } \\
\text { motor vehicles. }\end{array}$ & $10 \%$ \\
\hline $\begin{array}{l}\text { Motor Vehicle Fuel Tax } \\
\text { (PBBKB) }\end{array}$ & $\begin{array}{l}\text { 1. Private vehicle }= \\
\text { the highest is } 10 \% \text {. } \\
\text { 2. Public vehicles }= \\
\text { the lowest is } 50 \% \\
\text { lower than the cost } \\
\text { of private vehicle's } \\
\text { PBBKB. }\end{array}$ & $\begin{array}{l}\text { Vehicle Fuel Sale } \\
\text { Value before Charged } \\
\text { by Value Added Tax. }\end{array}$ & Not Clear \\
\hline $\begin{array}{l}\text { Underground Water } \\
\text { Tax (PABT) }\end{array}$ & - The highest is $10 \%$ & $\begin{array}{ll}- & \text { Surface Water } \\
& \text { Acquisition Value. }\end{array}$ & Not Clear \\
\hline $\begin{array}{l}\text { Street Lighting Tax } \\
\text { (PPJ) }\end{array}$ & $\begin{array}{l}\text { 1. The highest is } 10 \% \\
\text { for street lighting. } \\
\text { 2. The highest is } 3 \% \\
\text { for the use of } \\
\text { electricity from } \\
\text { other sources by } \\
\text { industry, petroleum } \\
\text { and natural gas } \\
\text { mining. } \\
\text { 3. The highest } 1.5 \% \\
\text { for the use of self- } \\
\text { generated street } \\
\text { lighting. }\end{array}$ & $\begin{array}{l}\text { - Selling Value of } \\
\text { Electricity }\end{array}$ & Not Clear \\
\hline Ground Water Tax & - The highest is $20 \%$. & $\begin{array}{ll}\text { - } & \text { Acquisition of Ground } \\
& \text { Water }\end{array}$ & Not Clear \\
\hline
\end{tabular}

Source: Law No.28/2009 concerning Local Tax and User Charge

Besides to the above taxes, there are several other types of state charges, essentially also pseudo environmental charges, such as cost for Environmental Impact Analysis (AMDAL), Life Environmental Management (UKL) and Environmental Monitoring Efforts (UPL) and also CSR as required by GR No. 27 of 2012 [8]. The cost of the various taxes and other state levies that can be categorized as pseudo environment tax and charges, by constructing the model by using the system dynamic analitical thinking. System dynamic analitical thinking commonly used to analyze hte implementation of public policy. The speciality of system dynamic is understanding the dynamics generated by systems composed of closedloop relations, which has ability of representing economic, social, and environmental issues through simple simulation models. The system dynamics that shows the relation between pseudo environment tax \& charges and its impact to the fiscal legitimacy, can be seen in Figure 2. 


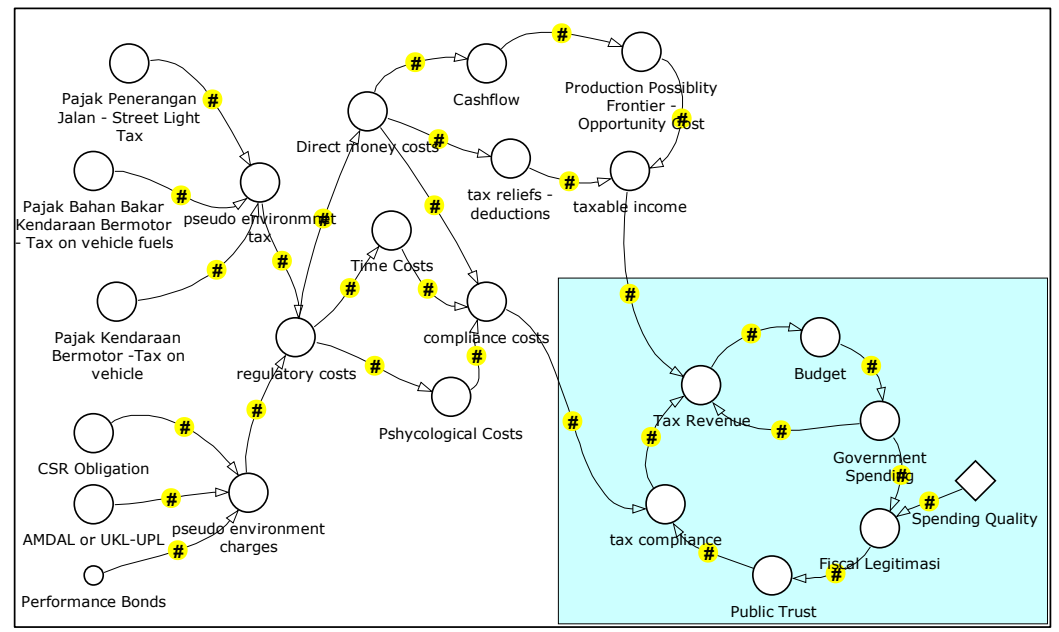

Fig. 2. Relationship between pseudo environment tax \& charges and fiscal legitimacy Source: data processing, 2018

From the figure above, it can be seen that various types of taxes and charges, in addition to disrupt the company's cash flow, also add direct money costs that must be issued by the company / taxpayer. Direct money costs are one factor that adds to compliance costs. The amount of compliance costs will affect to the tax compliance [9], because as the economic law states that "rational people think about profit / margin". Any addition of compliance costs will reduce the margin / profit to be received by the company / Taxpayer.

Implications if the government implements new types of taxes (e.g. environmental taxes) without making any simplification, harmonization and convergence of all pseudo environmental taxes and other levies which are pseudo environmental charges, can be described in Figure 3.

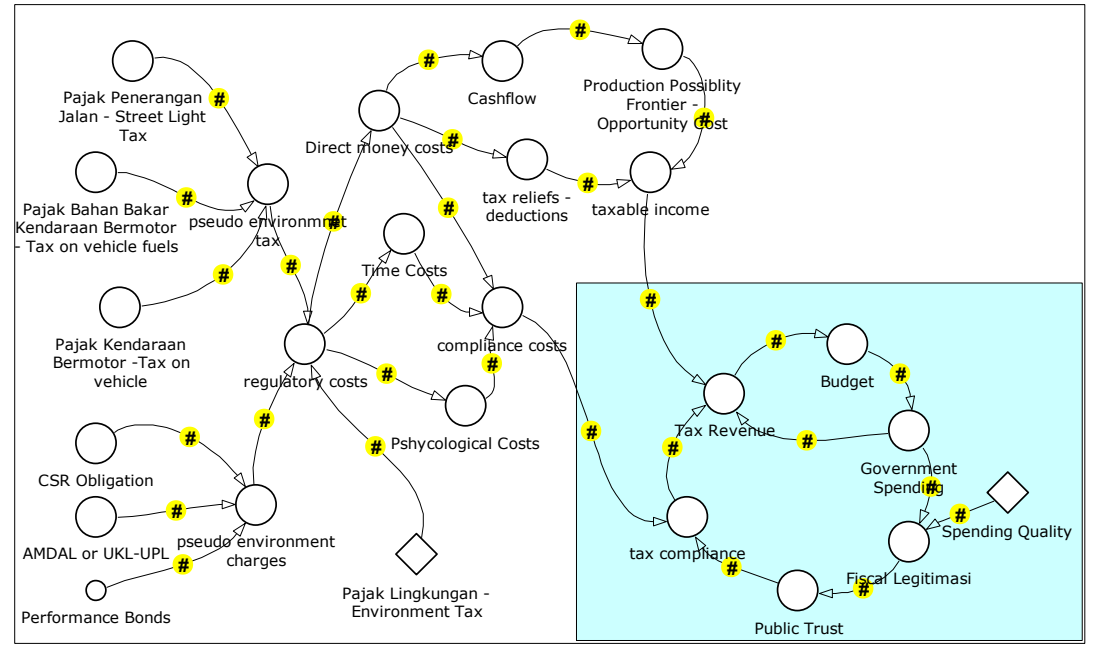

Figure 3. Implication of environment tax to cash flow and tax trust Source: Rosdiana, 2018

Instead of imposing new taxes to increase tax revenues, the application of new taxes (e.g., environmental taxes) will actually lower tax legitimacy which will ultimately lower government tax revenue. This can happen if in the implementation there are 2 (two) 
paradoxical phenomena, first the amount of regulatory cost increases and taxpayers consider cash flow is more limited to do productivity since the tax obligation will add new burden for business that eventually will retain them to invest into other business due to new state levies obligation. Secondly, if the government fails to obtain tax trusts from the people due to low spending quality as the function of government realocation of money collected, the government fails to get tax legitimacy from environmental taxpayers.

Figures 2 and 3, in fact, explain the phenomenon of why there is a rejection of environmental taxes that actually exist in the Law of the Republic of Indonesia Number 32 Year 2009 [10] About the Protection and Management of the Environment (UU PPLH). In Paragraph 8 of the Environmental Economics Instrument, Article 42 provides that "in order to preserve the function of the environment, the Government and regional governments shall develop and apply environmentally friendly economic instruments [11] by using environmental economic instruments including: a. development planning and economic activities; b. environmental funding; and c. incentives and / or disincentives. Furthermore, in Article 43 it is stipulated that incentives and / or disincentives among others are applied in the form of: a. procurement of goods and services that are environmentally friendly; $b$. application of taxes, user charges, and environmental subsidies.

In the elucidation of Article 43, it is explained that what is meant by "environmental tax" is levies by the Government and regional government on any person utilizing natural resources, such as underground water collection tax, fuel oil tax, and swallow bird's nest tax. Elucidation of Article 43, then PBBKB and PABT are actually part of environmental taxes. Therefore, the justification for enacting a new tax called the Environmental Tax is weak. Moreover, as seen in Table 1, earmarking is not fully applied properly and correctly to the pseudo environmental tax/and or charges, so that the public only sees it as an additional new tax burden.

From the perspective of evidence-based tax policy, mathematically, the calculation of compliance costs is not only based on the money spent on tax compliance, but also the intangible costs such as time costs and psychological costs, so that the following mathematical equations can be made:

$$
\text { Compliance Costs }=f \text { direct money costs }+ \text { time cost }+ \text { psychological costs }
$$

The greater the compliances costs the more reluctant people pay taxes, and they will seek to avoid taxes. From the government side, there are 2 (two) costs to be incurred are collection costs and policy cost. The combination of these three costs is called the cost of taxation. To obtain fiscal legitimacy, the government must ensure that cost of taxation is comparable to spending quality [12]. If spending quality is low, while cost of taxation is high, it is certain that the fiscal legitimacy will be low, which can be constructed with the following mathematical equations:

$$
\begin{gathered}
\text { Fiscal Legitimacy }=f \text { compliance costs }+ \text { collection costs }+ \text { policy costs }+ \\
\text { spending quality }
\end{gathered}
$$

On the other hand, the low level of fiscal legitimacy in the form of public reluctance to pay taxes (tax trusts) is also caused by spending quality government that has not been good and not as expected by the community. Good quality of public services, community satisfaction, and public trust, all three are related and closely related to each other. Guidance of the state to its citizens to abide by tax resulting in the consequences of increasing demand for public services [13]. That is why it becomes very important for the government not merely allocating various environmental taxes revenue for the preservation and maintenance of the environment, but proving that the use of budget allocations is realized with clear evidence. In addition, the government should also convince the public 
that tax revenue from environmental taxes that are not specific to the environment, will continue to be allocated to support the green growth policy, that is to rearch the growth that in the same time it has to preserve the environment.

Public money management is a domain where public trust [14] is at stake. Fiscal transparency and how the dialogue is built by the government with its citizens in determining spending decisions is the key in maintaining the trust of its citizens. According to Wagner's law, public expenditure and economic growth have a positive relationship [15]. In the present context, economic growth is not generally the goal, but leads to a more specific, namely green growth and green economic to create inclusive and sustainable development.

\section{Conclusion}

Indonesia has actually set Environmental Taxes and charges policy. This is evidenced by the existence of several types of taxes among others; PPJ, PBBKB, PKB, PAP and PABT. Therefore, Article 42 and Article 43 of the PPLH Law should not be interpreted by adding new types of tax levies in the form of environmental taxes. In addition to increasing compliance costs and distorting cash flow entrepreneurs, it will also impact on the lack of public trust in this government called distrust tax. If the government fails to manage revenue from environmental taxes and charges through good spending quality, then this new tax will cause high economic costs that reduces competitiveness, thereby reducing the source and economic activity that becomes the basis of tax revenue which leads to disruption of stability of state revenue. Therefore, instead of the government imposing new taxes, so that restructuring, convergence and harmonization of environmental taxes and charges must be made to achieve a connection between tax payments and inclusive and sustainable economic growth can be realized, in particular to achieve green growth policy in Indonesia. For the further work, it need to establish a model of expenditure management from the revenue mobilized for the purpose of environmental preservation.

\section{References}

1. A. Bakker. Tax and the environment: a world of possibilities (IBFD, Amsterdam, 2009)

2. M. Moore. How does taxation affect the quality of governance?. Working Paper 280, Institute of Development Studies. (2007)

3. R.A. Musgrave, P.B. Musgrave. Public finance in theory and practice (McGraw-Hill Book Company, New York, 1988)

4. H. Herdiansyah, T. Jokopitoyo, A. Munir. Environmental awareness to realizing green Islamic boarding school (eco-pesantren) in Indonesia. IOP Conference Series: Earth and Environmental Science 30012017 , (2016)

5. H. Herdiansyah, A.S. Utama, Safruddin, H. Hidayat, A.G.Z. Irawan. Analysis of environmental friendly library based on the satisfaction and service quality: study at library "X". IOP Conference Series: Earth and Environmental Science 88012030, (2017)

6. H. Widhiastuti. Studi meta-analisis tentang hubungan antara strees kerja dengan prestasi kerja. Jurnal Psikologi 29, 1 (2002)

7. Undang-undang Pajak Daerah dan Retribusi Daerah No. 28 Tahun 2009, Republik Indonesia. 
8. Peraturan Pemerintah Republik Indonesia Nomor 27 tahun 2012 Tentang Izin Lingkungan.

9. OECD. Co-operative tax compliance: building better tax control frameworks, OECD Publishing, Paris. http://dx.doi.org/10.1787/9789264253384-en. (2016)

10. Undang-Undang Republik Indonesia Nomor 32 Tahun 2009 Tentang Perlindungan Dan Pengelolaan Lingkungan Hidup.

11. Dewan Energi nasional 2016. Ketahanan Energi Indonesia 2015. Jakarta: DEN.

12. B. Welham, E. Hedger, P. Krause. Linkages between public sector revenues and expenditure in developing countries. ODI: Shaping policy for development. (2015)

13. UNFPA. State of world population 2011: people and possibilities in a world of 7 billion. (United Nations Population Fund, New York, 2011)

14. P. Arizti et al. Results, performance budgeting and trust in government (The World Bank, Washington D.C., 2010)

15. M. Afzal, Q. Abbas. Wagner's law in Pakistan: another look. Journal of Economics and International Finance 2, 1 (2010)

16. D. Streimikiene. Impact of environmental taxes on sustainable energy development in Baltic States, Czech Republic and Slovakia. Economie, XVIII, 4 (2015)

17. R. Diemer. Green taxation: a contribution to sustainability. Paper presented on The European Semester and Green Tax Reforms (environmental taxation and the removal of environmental harmful subsidies) - a Contribution to the wider fiscal consolidation process. (2013)

18. R. C. Wiliams III. Environmental taxation. Washington DC, Resources for the Future, Discussion Paper, RFF DP 16-24. (2016)

19. UNESCAP. Environmental tax reform in Asia and the Pacific. (2017) 